\title{
Studies on Male Fertility Regulation in Indonesia*
}

\author{
K.M. Arsyad
}

\begin{abstract}
Abstrak
Penelitian kontrasepsi untuk pria kurang mendapat perhatian jika dibandingkan dengan (untuk) wanira. Kondom dan sanggama terputus merupakan pilihan pertama kontrasepsi pria. Kedua cara ini biasanya merupakan inisiatif pasangan usia subur sendiri tanpa perlu nasihat dari dokter dan petugas KB. Pengembangan suatu cara KB pria yang aman, efektif dan reversibel merupakan langkah penting dalam upaya meningkatkan pilihan cara berKB pasangan usia subur untuk mengatur besar keluarga mereka. Makalah ini menjarikan sejumlah penelitian mengenai kontrasepsi pria yang dilakukan di Indonesia baik itu berupa kombinasi androgenprogestagen, androgen tunggal, cimetidine, ketoconazole, vasektomi tanpa pisau dan oklusi vas deferens dengan bahan silikon. Sebagian penelitian tersebut memberikan hasil yang memuaskan dan prospek yang baik untuk pengembangan cara KB pria y'ang aman dan efektif.
\end{abstract}

\begin{abstract}
Male contraception has not received much attention, compared with the extensive numbers of investigations dealing with female contraception. The condom and coitus interruptus were among the first methods of male contraception. These methods are usually started on the intiative of the couple, without any medical advice, as they are not ordinarily recommended in the family planning clinic. The development of safe, effective, and reversible contraceptive methods for men is an important step in increasing the options available for couples who wish to regulate their family size. This paper reviews the results of studies on male fertility regulation conducted in Indonesia, such as a combination of androgen-progestagen, androgen only, cimetidine, ketoconazole, nonscalpel vasectomy and vas occlusion using medical grade silicone. Some of those studies showed good results and prospectives in developing safe and effective contraceptive methods for men.
\end{abstract}

Keywords : hormonal, non-hormonal, male fertility regulation

\section{INTRODUCTION}

Male contraception has not received much attention, compared with the extensive number of investigations dealing with female contraception. The condom and coitus interruptus were among the first methods of male contraception. These methods are usually started on the initiative of the couple, without any medical advice, as they are not ordinarily recommended in the family planning clinic.

Improved methods for regulation of male fertility are required to expand family planning options among couples as the only reversible male methods currently

Division of Andrology Department of Medical Biology; Faculty of Medicine, Sriwijaja University, Palembang 30126. Indonesia

"Presented at the VIT National Congress and III International Symposium on New Perspecrives of Andrology in Human Reproduction, The Indonesian Society' of Andrology, September 19-24, 1994, Manado, Indonesia. available, interfere with coitus which linit their acceptability.

The fertility of the male is regulated by several factors:

1. The hormonal determinant which regulates steroidogenesis and spermatogenesis,

2. The male accessory glands and organs which are under strict hormonal control and which are responsible for the production of the seminal plasma, and

3. the psychogenic determinant which controls masculine behaviour and the libido of the male.

An ideal male contraceptive device is one which will not inhibit masculine behaviour and libido, but will reversibly inhibit the spermatogenesis till azoospermia and sperm fertilizing capacity for the desired period of contraception.

Testosterone adiministration has been proposed as a potential approach in male hormonal contraception as it can reversibly suppress spermatogenesis and cause 
testosterone-induced azoospermia and so, proved to be a highly effective form of contraception with minimal side-effects ${ }^{1}$. Most previous studies have however been conducted among men of European origin. ${ }^{2,3,4}$ In the first international multi-centre clinical study, testosteron enanthate (TE) were administered to a group of healthy fertile men at weekly doses of $200 \mathrm{mg}$ but azoospermia were achieved in only $70 \%$ of those men, with the remaining men becoming severely oligospermic. Striking differences between populations were observed in susceptibility to azoospermia as $91 \%$ of Chinese men but only $60 \%$ of non-Chinese men became azoospermic in that study. ${ }^{1}$ Progestin-androgen combinations also induce azoospermia at higher frequency in Indonesian compared with German men. 5,6,7 The reasons of these ethnic difference are yet unknown.

In order to increase participation and options for husbands in a family planning programme and to develop a safe and acceptable contraceptive method, some studies on male fertility regulation methods were done in Indonesia. The methods used in those studies include hormonal, non hormonal and surgical technics performed on human and animal.

\section{THE HORMONAL METHODS}

The hormonal methods consists of a combination of Androgen \& Progestagen, and Androgen only.

\section{Combination of Androgen \& Progestagen}

Depot medroxy progesterone acetate $(D M P A)+$ Testosterone Enanthate (TE)

A study using a combination of DMPA and TE were reported in $1991 .^{6}$ Twenty healthy fertile volunteers were allocated randomly to either of the two treatments, each consisting of four intramuscular injections at monthly intervals. Group I ( $n=10$ men) received 100 mg DMPA plus $100 \mathrm{mg}$ TE monthly, while group II ( $\mathrm{n}=10 \mathrm{men}$ ) received $200 \mathrm{mg}$ DMPA plus $250 \mathrm{mg}$ TE monthly. Sperm concentration was suppressed markedly, with all men attaining azoospermia between the third and fourth month after the onset of the injections. There was no significant difference in the suppression of spermatogenesis between the two dosage regimens. The median time in reaching azoospermia was 2.5 months from the onset of injections and the median time to recovery of sperms in the ejaculate was 2.0 months after cessation of treatment. No serious clinical side-effects were observed. Weight gain and increase in libido during treatment were reported by most of the volunteers.

\section{A combination of DMPA \& TE or 19-nortestosterone} hexoxyphenyl proprionate (19 NT)

A multicentre study in Indonesia using the two combinations were done by giving seven weekly injections of TE or 19 NT $200 \mathrm{mg} \mathrm{IM}$, followed by every 3 weeks injections up to week 24; and $250 \mathrm{mg}$ DMPA was injected IM at weeks $0,6,12$ and 18 in both groups. The results showed that 87 in 90 men $(96.7 \%)$ achieved consistent azoospermia; with $95.6 \%$ (43/45) and $97.8 \%$ (44/45) in the DMPA + TE and DMPA + 19 NT groups respectively. The remaining three men also were suppressed to near azoospermic level. Six of the initial 96 men were excluded from the study for failure to attend at the scheduled time (3) and for medical reasons (3). Median time of recovery of normal sperm concentration was 6.5 months.

The injection of DMPA + 19 NT or DMPA + TE in fertile men demonstrated that starting 12 weeks of injections there were no sperm with capacity to penetrate bovine cervical mucus in vitro. ${ }^{8}$

\section{A combination of DMPA \& Nandrolone Decanoate (ND)}

A combination of ND and DMPA injected on male rats showed a tendency to decrease the concentration of male rat sperm and reduces the percentage of motile sperm from the vas deferens. This study concluded that the injection of $1 \mathrm{mg} \mathrm{ND}$ and $2 \mathrm{mg}$ DMPA decreased the fertility of male rats. ${ }^{8}$

\section{Androgen only}

A study on the effect of TE only on sperm function of fertile men were reported in 1993 . $^{\circ}$ The treatment were given by weekly injections of $50 \mathrm{mg}$ or $100 \mathrm{mg}$ TE for 6 months and the effects were compared with a control group in which men received weekly intramuscular injections of $1 \mathrm{ml}$ sesame oil. The results demonstrated that the weekly dose of $50 \mathrm{mg}$ TE induced severe oligozoospermia in 4 of $7 \mathrm{men}$, whereas $100 \mathrm{mg}$ TE induced azoospermia in all 7 men by week 20 .

\section{THE NON HORMONAL METHODS}

The non hormonal methods consists of: Drugs, Plants, and Physics. 


\section{Drugs}

Cimetidine by intramuscular injection on male rats.

The result showed that with doses of $4.25 \mathrm{mg} / \mathrm{ml}$ and $8.50 \mathrm{mg} / \mathrm{ml}$, the numbers of spermatogonium $\mathrm{A}$ and pachyten spermatocyte were reduced, but the diameter of seminiferous tubules were not affected. ${ }^{8}$

The effect of a single dose of ketoconazole on sperm viability and motility of fertile men.

The results showed a decrement in the percentages of sperm motility (grade $a+b$ ) after four hours which stayed until day 7 , but there was no significant difference of effect between the 3 dosages. The percentages of sperm viability showed no difference. The spermicidal effect of this drug were not proven and no clear conclusion could be drawn about the doseresponse relationship. ${ }^{10}$

\section{Prostaglandin (PGE2) and Aspirin.}

A study on administration of PGE2 and aspirin per oral to adult male Wistar rats were reported in $1993 .{ }^{11}$ The PGE2 were given in two dosages $0.025 \mathrm{mg}$ and 0.05 $\mathrm{mg} /$ animal and aspirin in one dosage $0.5 \mathrm{mg} /$ animal. The result showed that PGE2 inhibit sperm maturation and decreased fertility up to $67 \%$ and spermatogenesis were disturbed at Meiosis I and II. Aspirin inhibits sperm maturation wthout any alteration on spermatogenesis. A combination of PGE2 and aspirin decreased the alteration in spermatogenesis, but increased the inhibition on sperm maturation.

\section{Plants}

Injections of the extract of $\mathrm{CH} 3$ Carica papaya with dosages of $10 \mathrm{mg}, 20 \mathrm{mg}$ or $40 \mathrm{mg} / 0.2 \mathrm{ml} /$ day on 40 male rats, showed no significant difference in the number of spermatogonium A, but there were a significant difference in the number of pachyten spermatocyte, especially with the dose of $40 \mathrm{mg}$. $^{8}$

The administration of the extract of Murray paniculata root $0.3 \mathrm{mg} / \mathrm{kg}$ body weight to male rats, showed decrements of the number of spermatozoa in vas deferens, the number of spermatogonium A, pachyten spermatocytes, motile sperms, viable sperms and diameter of seminiferous tubules. A dose of $0.6 \mathrm{mg} / \mathrm{kg}$ bodyweight proved to be most effective in controlling male rat fertility in terms of sperm function impairment. ${ }^{8}$
The extract of Avicennia marina (Forsk) vierh.

A dose-response relationship were found in a study on the effect of the extract of Avicennia marina (Forsk) vierh on the ultrastructure of mice testis. ${ }^{12}$

\section{Physics}

Repeated heating on mice testicle at $40^{\circ} \mathrm{C}$ showed that there were no significant differences in the number of broken sperm compared to control. At $41^{\circ}$ and $42^{\circ} \mathrm{C}$ there were significant differences in the number of broken sperm compared to control ${ }^{8}$.

\section{THE SURGICAL METHODS}

The surgical methods consists of:

Nonscalpel vasectomy (NSV)

The efficacy and acceptability study of nonscalpel vasectomy (NSV) which was done in Palembang, demonstrated that the efficacy reached on month 3 after NSV was $88 \%$, on month 6 after NSV was $100 \%$ but decreased to $96 \%$ at month 12 after NSV. One year after NSV, all volunteers held with their decision to be acceptors and there were no regretfulness regarding their decision.

The complications recorded were:

In the first month after NSV, 1 volunteer with small scrotal hematoma and 3 volunteers with scrotal skin infection. Twelf months after NSV 6 volunteers reported low back pain.

\section{Vas occlusion}

A comparation between Medical Grade Silicon Rubber (MSR) vas occlusion using an oval $15 \mathrm{~mm}$ clamp with appropriate volume derived from the volume study $(n=58)$ and non-scalpel vasectomy (NSV) as standard procedure $(n=64)$, were reported in $1994 .{ }^{13}$ The azoospermic rate following MSR vasocclusion which was achieved in 3-6 months, was not significantly different from that, following NSV.

\section{CONCLUSION}

Studies about hormonal and vas occlusion methods showed good results and prospectives in the development of safe and effective contraceptive methods for Indonesian men.

The WHO task force on methods for the regulation of male fertility ${ }^{14}$ is also aiming to provide a choice through research programs involving the following broad areas : 


\section{Hormonal methods for men}

The studies carried out in this area have focused on three main approaches: (a) the inhibition of spermatogenesis by suppression of the secretion of gonadotropins both LH and FSH, or FSH only; (b) the recovery of circulating androgen to physiological levels without restimulation of spermatogenesis; and (c) the assessment of functional capacity of residual sperm, if the treatment fail to achieve azoospermia in all cases.

\section{Male sterilization}

There are three main factors which limit the acceptability of vasectomy. The first is concern about safety of the approach, in particular about the risk of inducing or promoting malignancy; the second is the need for a skin incission, which is unacceptable in some cultures; and third is the lack of certainty regarding reversibility, should man wish to reattain fertility some time in the future.

Drugs and plant products for inhibition of sperm maturation.

To assess which of the methods of male contraceptives would be most acceptable to fertile couples in Indonesia, some researches on new options for male fertility regulation should be promoted and supported by both government and international agencies.

\section{REFERENCES}

1. World Health Organization Task Force. Methods for the regulation of male fertility: Contraceptive efficacy of testosterone induced azoospermia in normal men. Lancet 1990;336:955-9.

2. Patanelli DJ. (ed) Hormonal control of fertility. US Department of Health: Education and Welfare. Washington, 1977.
3. Paulsen CA. Male contraceptive development: Re-examination of testosterone enanthate as an effective single entity agent. In: Hormonal control of male fertility. US Department of Health: Education and Welfare. Washington, 1978:17-40.

4. Swerdloff RS, Palacios A. Male contraception: Clinical assessment of chronic administration of testosterone enanthate. Int J Androl 1978;(2Suppl):731-47.

5. Knuth UA, Yeung CH. Combination of 19-nortestosterone hexoxyphenylproprionate (Anadur) and depot medroxyprogesterone acetate (Clinovir) for male contraception. Fertil Steril 1989;51:1011-8.

6. Pangkahila W. Reversible azoospermia induced by androgen-progestagen combination regimen in Indonesian men. Int J Androl 1991;44:248-56.

7. World Health Organization Task Force. Methods for the regulation of male fertility; An Indonesian multicentre study: Comparison of testosterone enanthate plus DMPA and 19nortestosterone hexoxyphenyl propionate plus DMPA for male contraception. Fertil Steril 1993;60(6):1062-8.

8. Moeloek N. Several unale fertility regulation studies in Indonesia. The $\mathrm{X}^{\text {th }}$ Indonesian Society of Andrology Annual Meeting; 1993 Nov 16-17; Denpasar, Bali.

9. Arsyad KM. Sperm function in Indonesian men treated with testosterone enanthate. Int J Androl 1993;16:335-61.

10. Arsyad KM, Syofyan Syah, Triwani. Efek Ketoconazole dosis tunggal pada mobilitas dan viabilitas spermatozoa. In press.

11. Jatim W, Salmiati, Sarifudin. Efek Prostaglandin dan Aspirin terhadap spermatogenesis, maturasi spermatozoa dan fertilitas tikus jantan. The $\mathrm{X}^{\text {th }}$ Indonesian Society of Andrology Annual Meeting; 1993 Nov 16-17; Denpasar, Bali.

12. Indrayanto $Y$, Soehadi K. Pengaruh pemberian ekstrak buah Avicennia marina (forsk) vierh terhadap gambaran struktur ultra testis mencit. The Xth Indonesian Society of Andrology Annual Meeting; 1993 Nov. 16-17; Denpasar, Bali.

13. Soebadi DM, Gardjito W, Mensink HJA. Intravasal injection of formed-in-place medical grade silicone rubber for vasocclusion. In press.

14. World Health Organization. Special program of research development and research training in Human Reproduction. UNDP/UNFPA/WHO/World Bank; Biennial Report; 19921993:WHO;1994. 